\title{
Computerization of primary health care in Brazil: the network of actors
}

\author{
Informatização da atenção primária à saúde no Brasil: a rede de atores \\ Informatización de la atención primaria a la salud en Brasil: la red de actores
}

Ricardo Bezerra Cavalcante'

ORCID: 0000-0001-5381-4815

Cristiano José da Silva Esteves'

ORCID: 0000-0001-8917-8363

Tarcísio Laerte Gontijo'

ORCID: 0000-0001-7845-3825

Maria José Menezes Brito"

ORCID: 0000-0001-9183-1982

Eliete Albano de Azevedo Guimarães'

ORCID: 0000-0001-9236-8643

Simone de Pinho Barbosa"'

ORCID: 0000-0003-1073-3219

'Universidade Federal de São João Del-Rei. São João del-Rei-MG, Brasil.

"Universidade Federal de Minas Gerais. Belo Horizonte-MG, Brasil.

"I' Universidade Federal de Juiz de Fora. Juiz de Fora-MG, Brasil

How to cite this article: Cavalcante RB, Esteves CJS, Gontijo TL, Brito MJM,

Guimarães EAA, Barbosa SP. Computerization of primary health care in Brazil: the network of actors.

Rev Bras Enferm [Internet]. 2019;72(2):337-44. doi: http://dx.doi.org/10.1590/0034-7167-2018-0381

\section{Corresponding Author:}

Cristiano José da Silva Esteves

E-mail: cristianoxkm@hotmail.com

Submission: 06-18-2018

Approval: 08-03-2018

\section{ABSTRACT}

Objective: To analyze the network of human and non-human actors involved in the computerization of primary health care in the Brazilian federal government. Method: A qualitative study that used as a theoretical reference the actor-network theory and as a methodological reference the cartography of controversies. Data analysis was carried out using Gephi software, and through the extraction of reports, informed by the actor-network theory. Results: We found a network of 288 connections among 33 actors, composed mainly of nonhuman influencers of computerization. These actors are distributed throughout 3 inter-related communities, and manage the network by defining obligations, penalties, conflicts and intentionalities, thus influencing the success of the intended computerization. Final considerations: The network of actors at the federal level generates situations that, in many cases, hamper the successful implementation of a nationwide computerization strategy.

Descriptors: Nursing Informatics; Medical Informatics; Primary Health Care; Information Technology; Family Health.

\section{RESUMO}

Objetivo: Analisar a rede de atores humanos e não-humanos envolvidos na informatização da atenção primária à saúde na esfera federal do governo brasileiro. Método: Estudo qualitativo que utilizou como referencial teórico a teoria ator-rede e como referencial metodológico a cartografia de controvérsias. A análise dos dados se deu por meio do software Gephi e a partir da técnica de extratos de relatos com ponto de vista da teoria ator-rede. Resultados: Constatou-se uma rede de 288 ligações entre 33 atores, composta majoritariamente por não-humanos influenciadores da informatização. Os atores estão distribuídos em 3 comunidades, que se relacionam entre si, agenciando a rede a partir da definição de obrigatoriedades, penalidades, conflitos e intencionalidades, influenciando o sucesso da pretendida informatização. Considerações finais: A rede de atores na esfera federal mobiliza situações que, em muitos momentos, obstaculizam o sucesso da implantação de uma estratégia de informatização de abrangência nacional.

Descritores: Informática em Enfermagem; Informática em Saúde; Atenção Básica à Saúde; Tecnologias da Informação; Saúde da Família.

\section{RESUMEN}

Objetivo: Analizar la red de actores humanos y no-humanos que están involucrados en la informatización de la atención primaria a la salud en la esfera federal del gobierno brasileño. Método: Estudio cualitativo que ha utilizado como referencial teórico la teoría actor-red y como referencial metodológico la cartografía de controversias. El análisis de los datos se dio por medio del programa Gephi y desde la técnica de extractos de relatos con punto de vista de la teoría actor-red. Resultados: Se ha constatado una red de 288 conexiones entre 33 actores, que está conformada mayoritariamente por no-humanos influyentes de la informatización. Los actores están distribuidos en 3 comunidades, que se relacionan entre sí, agenciando la red desde la definición de las obligatoriedades, las condenas, los conflictos y las intencionalidades, influyendo el éxito de la pretendida informatización. Consideraciones Finales: La red de actores en la esfera federal moviliza situaciones que, en muchos momentos, obstaculizan el éxito de la implantación de una estrategia de la informatización de abarcadura nacional. Descriptores: Informática en Enfermería; Informática en Salud; Atención Básica a la Salud; Tecnologías de la Información; Salud de la Familia. 


\section{INTRODUCTION}

In 2013, the Brazilian Ministry of Health established the e-SUS Primary Care strategy (e-SUS AB) ${ }^{(1)}$, with the intention of computerizing Primary Health Care (PHC) throughout the national territory. The strategy employed two software systems, the Simplified Data Collection (CDS) and the Electronic Citizen's Medical Record (PEC), in addition to all necessary technological infrastructure: computers at all points of care; qualified broadband internet access; transportable devices for registration; among others ${ }^{(2)}$.

The e-SUS AB strategy brings possibilities for advancements and improvements in information use ${ }^{(3)}$. However, its success depends not only on technical aspects, but also on the acceptance of the various involved actors, and their mobilization towards the goal of computerization ${ }^{(4)}$. Indeed, for a strategy that aims to computerize the entire PHC service to be successful, it needs to go beyond technical attributes per se. One needs to think in terms of sociotechnical relations as a network of human or nonhuman actors, at a given time and place ${ }^{(5)}$. In order to understand these sociotechnical relations, which underlie the e-SUS AB strategy, the Actor-Network Theory (ANT) is presented as an appropriate theoretical referential ${ }^{(6)}$-also applicable in the context of health and nursing ${ }^{(7)}$.

In ANT, human and nonhuman actors, also called "actants," have the capacity for agency because they participate in a network's actions, transforming it. In turn, the "network" is understood as the interactions between these actants, and yet every actor is a network, just as every network can be an actor. The social dynamic is not simply the actor, or the network in which the actor is inserted, but the association between these entities, as well as the exchanges across their connections. The perspective of the social dynamic as being comprised of several nodes and multiple relations allows one to follow along and delineate the production of phenomena ${ }^{(6)}$.

Although the e-SUS AB strategy was recently instituted and is in its early stages of implementation, studies have shown that, in addition to human actors, nonhumans also have a role in their implementation, as they influence PHC professionals and their daily work ${ }^{(3,8)}$. Thus, for the implementation of this strategy to be successful, it is important to identify the participating humans and nonhumans and how they relate in the network, describing their influences, especially at the federal level, the instance responsible for the strategy's conception and planning, to be adopted by the states and municipalities. In this sense, we came up with the following guiding question: How is the e-SUS AB network of actants formed in the government's federal sphere?

\section{OBJECTIVE}

To analyze the network of human and nonhuman actors involved in the computerization of primary health care in the Brazilian government's federal sphere.

\section{METHODS}

\section{Ethical aspects}

This study is in accordance with Resolution 466/2012 of the National Health Council and was submitted to the Committee of
Ethics in Research with Human Beings of the Federal University of São João del-Rei, where it was authorized.

In order to guarantee the anonymity of the human actors of

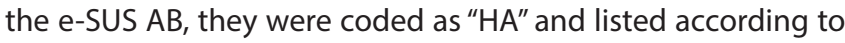
their order of appearance.

\section{Theoretical-methodological reference and type of study}

This is a qualitative study, in which ANT was used as a theoretical reference. The ANT proposes to follow and map actants' movements and the influences traversing their reciprocal connections. Its task is to map and delineate the network's dynamics, tracing actors in the act of their agency and mapping these traces ${ }^{(6)}$.

Our methodological reference was the "cartography of controversies," considered a set of techniques to explore and visualize controversies and discussions, observing and describing social debate, especially_but not exclusively_around technical and scientific problems ${ }^{(9)}$.

\section{Scenario of the study}

The cartography of controversies contemplates four movement pathways that have to be traversed ${ }^{(10)}$. Firstly, it is necessary to search for a gateway into the network (initial scenario), which, in the case of this study, was the site of the Department of Primary Care (DAB) of the Ministry of Health. This was a conscious choice, considering that the e-SUS AB strategy is conceived at the federal level. The Ministry of Health acts as a regulatory body, and the DAB website is the locus where all supporting materials, including legislation, communication channels, and software systems are available for states and municipalities to download.

When walking through the network in pursuit of its actors, the researcher can be directed to other scenarios ${ }^{(6)}$. From the DAB website we were directed to a virtual community-the Community of Practices/e-SUS AB (Comunidade de Práticas/e-SUS $A B$ ) - a relevant communication channel indeed, since it proved to be a medium of extreme importance for this study's object, providing us with countless debates and declarations from the most diverse actors, acting at different governmental levels.

\section{Source and data collection}

The second pathway is the identification of spokespersons representing the network ${ }^{(10)}$. We attempted to establish the relationships between all actors, including concordant and discordant voices. One of the network's spokesmen was the Minister of Health. However, spokespersons have also emerged from municipalities, regional health centers and states, leaving their traces (i.e., speeches) in the Community of Practices/e-SUS AB online platform.

During the data collection period, which took place between August 2016 and October 2017, the researchers mapped a series of posts on the Community of Practices/e-SUS AB portal (published between January 2015 and October 2017), with the purpose of assimilating the perceptions of the most diverse operators of the e-SUS AB strategy throughout the country. A database containing around 48 posts was generated and analyzed using the "Extracts of reports based on the Actor-Network Theory" technique. 
The third movement pathway is the access to inscription devices, that is, every script or visual exposition able to materialize the network ${ }^{(10)}$. Inscription devices were cataloged as follows: manuals, ordinances, directives, edicts, minutes, technical notes and public notes, dealing with the object under study. Such devices were available on the websites of the following organs: Ministry of Health; DAB; Tripartite Interagency Committee (CIT); National Council of Health Secretaries (CONASS); National Council of Municipal Health Secretariats (CONASEMS); and the Technical Chamber of Information and Health Informatics of the CONASS (CTIIS).

\section{Data analysis}

The analysis using the "cartography of controversies" method comprises the fourth movement pathway: the mapping of associations. It is a question of delineating and analyzing the links established between the various actors (human and nonhuman) that make up the network ${ }^{(10)}$.

To this end, the following procedures were performed ${ }^{(10,11)}$ : exhaustive reading of the information extracted from the inscription devices; in-depth description of the social dynamics of the studied phenomenon, reaggregating events and ordering them chronologically; identification of the mediating actants (those that modify the network) described in the inscription devices and directly involved with the object of study; identification of the connections between actants based on the description of the object of study (connections are considered to exist when there is some kind of relationship between two actants-conflict, agreement, divergence, questioning, synergy, among others); creation of a database containing nodes (actants) and edges (links). We identified 33 nodes and 288 edges.

In order to visualize the connections between the network's actants, the visual display tools of the Gephi 0.9.1 software ${ }^{(12)}$ were used, by importing the database created by the researchers to the software's "Data Laboratory." Each node of the Gephi network can be considered an actant, whose thickness and the size of its source corresponded to the number of edges (Degree of connection) it has with the other nodes. The edges were assigned the "Undirected" type, for cases when the connection between two nodes is necessarily reciprocal.

In the "overview" tab of the software, the following procedures were performed to change the network's appearance: execution of "modularity" analysis; coloring of the nodes using the "Partition - Modularity Class" function; stipulation of the size of the nodes and the source according to their "Degree"; and use of the "ForceAtlas 2" standard layout algorithm.

Based on these parameters, the software automatically generated the network, allocating its nodes according to link affinities and giving rise to agglomerations of strongly connected nodes called clusters, which, in sociotechnical terms, represent commoninterest groups (communities). These were differentiated by colors to facilitate their interpretation.

We also made use of the technique"Extracts of reports based on the Actor-Network Theory"(13). In this analytical technique, excerpts that illustrate the network's connections are extracted from the collected reports. These excerpts help to understand the interaction between actants and were essential for the task of interpreting the network, conferring it meanings mediated by ANT's concepts.

\section{RESULTS}

The network of human and nonhuman actors involved with the e-SUS AB strategy at the federal level (Figure 1) has 3 clusters. The first one is comprised of the MINISTRY OF HEALTH and other actants, which appear in purple; the second is made by the components of the DAB SITE, in orange; and the third by the following agglomerate of actants: CIT; CONASS; CONASEMS; CTIIS and its Technical Notes (NT), shown in green.

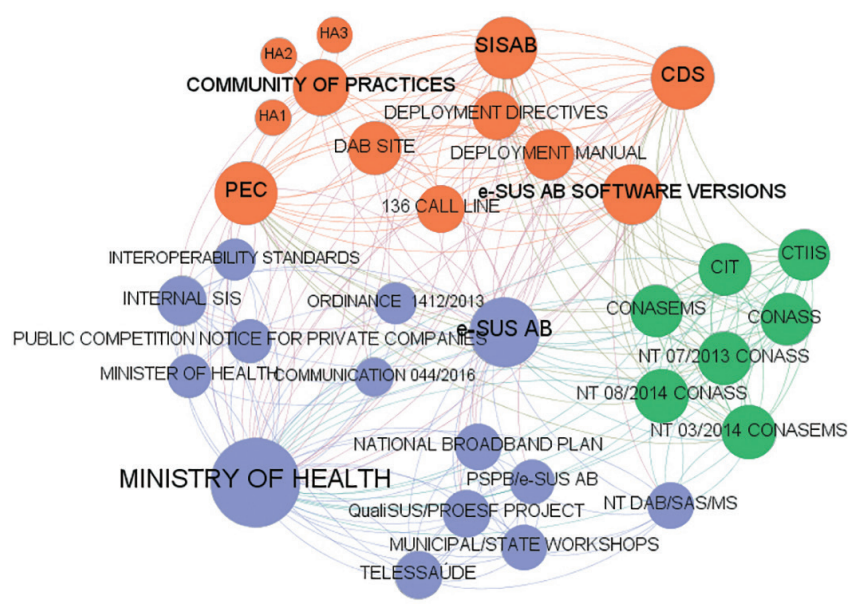

Figure 1 - The network of human and nonhuman actors of the e-SUS Primary Care Strategy (e-SUS/AB) at the federal level, Brazil, 2017

It is worth pointing out that the greater visibility of the actants MINISTRY OF HEALTH, e-SUS AB, e-SUS AB SOFTWARE VERSIONS, PEC, COMMUNITY OF PRACTICES, SISAB and CDS is due to the high number of connections they have with the other actors in the network, showing their importance and centrality in the analyzed registration devices.

Determinations and legislation for the implementation process of the e-SUS AB strategy stem from the purple cluster, comprised of the largest number of actors in the network and guided by the Ministry of Health. In the course of the network's social dynamics, this cluster influences the implementation of the strategy through standardization, deployment actions and guidelines, as illustrated by the figure, but also through mandates and penalties, as shown in the following excerpt:

[...] as of January 2016, the information must be sent to the SISAB database. The failure to send information to SISAB for three (3) consecutive mandates will warrant the suspension of resources received from the Primary Care Block ... ${ }^{(14)}$.

Another nonhuman actor, appearing with a high Degree in the purple cluster, is "PUBLIC COMPETITION NOTICE FOR PRIVATE COMPANIES," which represents the opening of the public space to software companies aiming at the implementation of the eSUS AB strategy in the municipalities. This is done by means of: 
Company hiring, through accreditation, to implement electronic medical records in the Basic Health Units, by means of a solution that includes hardware, software, maintenance of IT equipment, training of health professionals and technical support for use of the Electronic Medical Record, as specified in this basic project and its Appendices ${ }^{(15)}$.

When only the network of connections is extracted from the software, the nonhuman actor "PUBLIC COMPETITION NOTICE OF PRIVATE COMPANIES" has its edges connected only with the actants MINISTER OF HEALTH, MINISTRY OF HEALTH, INTERNAL SIS, INTEROPERABILITY STANDARDS and PEC (Figure 2). Such conformation of the network demonstrates a relationship of proximity and exclusivity of bonds between such actants.

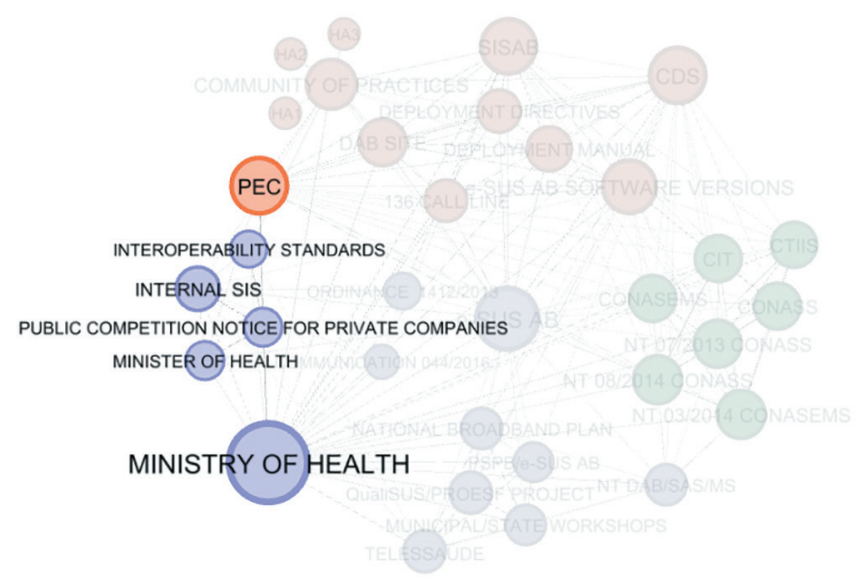

Figure 2 - Network of connections belonging to the node "PUBLIC COMPETITION NOTICE FOR PRIVATE COMPANIES," of the e-SUS Primary Care (e-SUS AB) federal strategy, Brazil, 2017

Another nonhuman belonging to the purple cluster is "INTEROPERABILITY STANDARDS." Through the reports available in the Community of Practices, one can clearly see that a considerable range of Brazilian municipalities makes use of private health information systems (INTERNAL SIS), which do not share the standards of interoperability and health information determined by Ordinance $2073^{(16)}$. As a consequence, some municipalities have difficulties exporting their health data to the ministerial base:

\begin{abstract}
I imported the thrift file from third-party software and the BPA and the reports from the unit where I am using the third-party software appear blank. I have already tried support via the 136 [call line], via email with the DAB and I have read forum posts about the problem, however there are only users complaining, no one who has already found a solution to the problem came to the forum to share it! Has anyone seen this problem? Do you know how to solve it? I need help! (HA1)
\end{abstract}

In the orange cluster are the software systems related to the e-SUS AB strategy, their updates, the support materials, communication channels and parameters for their deployment. This cluster has many links with the purple cluster, precisely because the $D A B$ is an internal instance of the Ministry of Health, being responsible for making the computerization process operational.
The "e-SUS AB VERSIONS" node also emerged as a nonhuman with many links in the network; thus, its prominence in the orange cluster (Figure 1). This is due to the various updates carried out by the Ministry of Health and made available to municipalities on the DAB website. With each new version, CDS and PEC software systems undergo changes in their functionality: new input forms are created or modified, and new support materials are made available. However, the various updates have promoted difficulties for the adaptation of $A B$ professionals, as pointed out in the Community of Practices:

ERROR IN THE NEW VERSION OF THE PEC. 2.2.09 - FAILS TO GENERATE REPORTS. Good morning! Version 2.2.09 of the PEC does in fact have this error: it does not generate the reports and it does not process the files. I had to go back to the previous version because we need to generate some reports and the new version fails to do so. I think they should have tested this before releasing the new version, as downgrading to previous versions of the PEC is very laborious. (HA2)

In the orange cluster, it is important to emphasize the relevance of the nonhuman "COMMUNITY OF PRACTICES." This actant highlights weaknesses in the implementation of the e-SUS AB strategy in the states and municipalities:

\begin{abstract}
I have the same issue. There's barely any intelligent support for the e-SUS system, and that's the truth: when you call 136, and they hardly know the basics. My e-SUS is installed on a single $P C$, with the ORACLE database, and I have had this problem for some time now. I have already called them, but no one is able to explain me how to solve the issue. Ah, and there's more! I had to figure out the installation into ORACLE myself, since the e-SUS website doesn't tell you how to do anything. That's what you get for building a system using rookie personnel and without a test base, just to see how far it can go. I'm already thinking about hiring a third-party company again, because support was better, and they were actually able to solve the problem. They take their time, but they do solve it. (HA3)
\end{abstract}

The green cluster (Figure 1), comprised of the nonhuman actors CONASS, CTIIS, CIT, CONASEMS and their Technical Notes are a community with greater inter-node proximity. Besides, their nodes are about equally sized, pointing to a certain homogeneity in the number of links between these nodes and also to their non-centrality.

These actants make observations on the e-SUS AB computerization strategy by issuing Technical Notes (NT) (NT07/2013 CONASS; NT08/2014 CONASS; NT03/2014 CONASEMS), highlighting:"lack of software testing"; "information security issues;"'deficiencies in reports generated for municipal and state management"; "need for re-registration of the entire population"; "underestimated costs"; "need for deadline extensions"; "need for building professional capacities"(17-19).

In response to the notes made by CONASS and CONASEMS, the Ministry of Health issued another nonhuman actant, a Technical Response Note (NT DAB/SAS/MS) (Figure 3), in an attempt to answer to certain demands, highlighting its initiatives to address criticism: "implementation of the NATIONAL BROADBAND PLAN"; "Organizing several STATE AND MUNICIPAL WORKSHOPS"; "Approval 
of TELESSAÚDE groups for training purposes"; "Loans (QualiSUS/ PROESF PROJECT) to finance the implementation of the e-SUS $A B$ strategy"; and the "accountability of states and municipalities in the construction of the e-SUS AB Community, in the Brazilian Public Software Portal" (PSPB/e-SUS AB) ${ }^{(20)}$.

\section{DISCUSSION}

The network of actants involved in the debate around the eSUS AB strategy at the federal level is composed of many links between several nodes. In this network, nonhumans, represented by instances, documents and policies, are also responsible for social action, active in the process of technology deployment and, therefore, can positively or negatively influence such process.

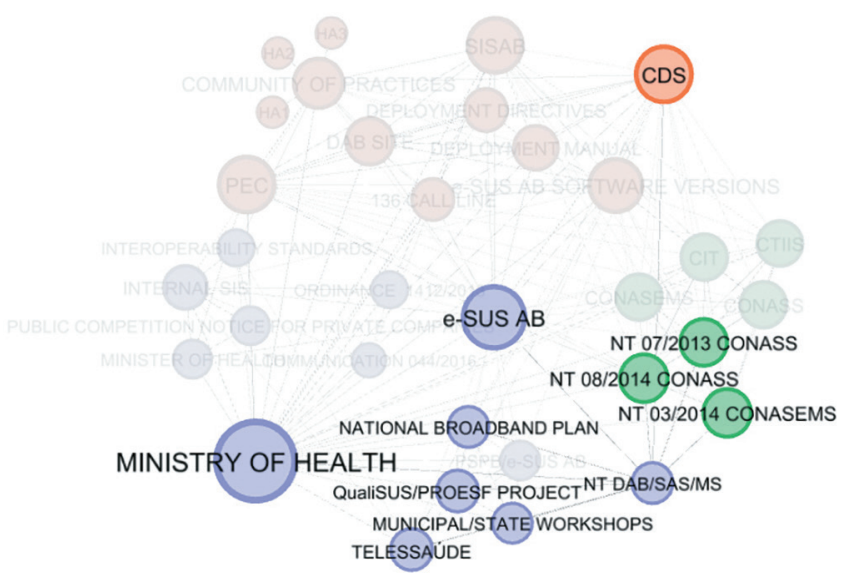

Figure 3 - Network of actants and their connections, starting from the Technical Response Not by the Ministry of Health (NT DAB/SAS/MS/2014), part of the federal e-SUS Primary Care (e-SUS AB) strategy, Brazil, 2017

Even at the federal level, the e-SUS AB strategy is influenced by networked relationships, in which each actant transcribes the strategy according to its intentionalities. This process is permeated by pressures, obligations, normalizations, penalties, openings to the private market, inquiries, suggestions and conflicts.

Thus, the conceptualization of the e-SUS AB strategy, initiated at the federal level in Brazil, evokes a complexity that goes beyond providing adequate technology and infrastructure. The conformation of the network of actants that compose the federal sphere involves several actors who think about the object and demand its modification, making the network dynamic, incessantly constructed, deconstructed and reconstructed, showing that the social, in this context, is always in action ${ }^{(21)}$. In addition, the mapped network is also characterized by the consolidation of three clusters (communities) that relate to each other and to other communities, in connections that alternately interpenetrate, approach or assume distance from each other, reinforcing that the process of deployment of a technology is made in and with the network.

The most prominent actant in the network is the Ministry of Health: its high Degree (number of connections) to the other actors characterizes it as the main mediator and emitter of influences that modify the network ${ }^{(6)}$. It is only natural for this nonhuman to have a certain protagonism, since its prerogative is to conceive the strategy and promote its deployment in other governmental instances. It does so by issuing norms, demanding their compliance and, at times, penalizing non-implementation.

However, this way of mobilizing the network suggests a historical imperfection in the conception and management of information technologies in the context of Brazilian public health, which may induce states and municipalities to comply with such requirements with little actual interest in participating in a collective process, and freely discussing the planned and systematized implementation of technological innovations ${ }^{(22)}$. As a consequence, health professionals may behave as mere "data collectors" whose priority is to transmit them to central levels, thus depriving them the possibility of creating and attributing meaning to the technology ${ }^{(23)}$. It is very possible that health professionals do not recognize technology as an ally in local decision-making, aiming at the qualified management of care based on reliable information ${ }^{(24,25)}$.

This situation contradicts the premise of the e-SUS AB strategy, which aims to improve work processes by individualization the health registry; integration of information; elimination of rework; and the management and qualification of healthcare in the health care locus ${ }^{(26)}$.

Another influence of the Ministry of Health, which enhances its prominence in the network by modifying it, is the opening of the public space to the private information technology market. In this context, companies will be able to take over the process of implementation and maintenance of the e-SUS AB strategy in the UBS, from offering physical and technological infrastructure to training professionals ${ }^{(15)}$. This decision can erode the responsibilities of the public health spheres for the process of technology deployment, as well as reinforce the imbalance of public-private relations ${ }^{(27,28)}$

It is also an expression of a recurrent national tradition in the last decades, in which the public sector, aiming to compensate for its ineffectiveness at the deployment of technologies, opens itself to technological conglomerates ${ }^{(24)}$. However, success by private means is by no means a guarantee, while the historical plundering of the public machine will burden the nation for long periods of time ${ }^{(29)}$.

The issue of public-private relations needs attention, since the contracts governing them may have frail regulations. In addition, it is necessary to provide an adequate institutionalization environment, so that technology legitimizes itself in the eyes of the health professionals, who, in turn, must be engaged in it, creating balanced public-private partnerships ${ }^{(30)}$.

In this study, we were able to verify issues and questions reported in other networks, representative of the Brazilian states and their municipalities. These reports exerted influence over the federal network, since they represent a feedback mechanism which takes place in states and municipalities, the locus of technological deployment. These concordant and discordant voices from state and municipal levels also make up a network, with its entanglement of actors. They are apparently autonomous branches of the general process, or an effect of this very process, which up to a point remained stable due to the involved actants. However, because of a certain controversy they began 
to externalize criticisms and issues that had an influence able to overlap their own network, and this may or may not be met with resistance, depending on the intensity of these manifestations ${ }^{(6)}$.

Thus, in the federal network of actors, it is already possible to hear voices from states and municipalities pointing to certain aspects of the real panorama of primary care computerization via the e-SUS AB strategy. In this sense, what can be extracted from these other networks are reports that alert to weaknesses of the process: continuous changes in software versions that end up negatively influencing the professionals' workflow; difficulties for municipalities that have their own internal SIS to dump their data into the Health Information System for Primary Care (SISAB); reports from advisory bodies diagnosing deficiencies and requesting adjustments; difficulties reported by users in the Community of Practices, generating resistance; and other difficulties in the municipalities and states, which jeopardize the system's deployment.

Even if they are only latent, such frailties have already been observed in previous processes of deployment and use of information systems in the context of the Brazilian PHC. Studies show that the inadequate use of data collection instruments compromises the quality of information ${ }^{(31)}$. In addition, according to the scientific production about the old Primary Care Information System (SIAB), in addition feeding the system with nonconformities, health professionals used it merely as a registration form ${ }^{(32)}$. A recent integrative review $^{(33)}$ discusses reports by national studies of weaknesses in the implementation of health information systems, data inconsistencies and lack of standard terminology. Its findings reinforce the idea that the implementation of the e-SUS AB strategy reproduces certain historical problems related to the deployment of technologies in the context of Brazilian public health.

\section{Limitations of this study}

The high number of nonhuman actors in comparison to human actors present in this study is associated with the fact that we were willing to use published documents to map the network of actants. This fact may be considered a limitation of the study and at the same time serve as a suggestion for future research.
Further studies are therefore recommended, in order to map the networks of actants and their influences on the process of implementing the e-SUS AB strategy at the state, regional and municipal levels.

\section{Contributions to the area of nursing, health or public policy}

Considering the current panorama of implementation of the e-SUS AB strategy in the federal context, this study's findings can guide interventions, public policies and new strategies that potentiate the use of information technologies in the $\mathrm{PHC}$, taking into account the reality of networked socio-technical relations.

\section{FINAL CONSIDERATIONS}

At the federal level, the network of actors is mostly comprised of nonhuman actors who have the capacity for social action, influencing the e-SUS AB strategy. The social action carried out in this context is based on the relationships established between these actors in a dynamic network, generating situations that, in many moments, hinder the deployment of a national-scope computerization strategy.

The conformation of the network of actants that compose the federal sphere involves several actors, in various instances; these actors imprint their intentionalities and, therefore, modify the e-SUS AB strategy, making the network dynamic and complex. We can already hear voices from states and municipalities pointing out weaknesses in the concrete panorama of the strategy's deployment. These weaknesses need to be overcome, so that the computerization initiative is not frustrated and that ABS professionals are able to create meanings for the use of information technologies, legitimizing them.

\section{FINANCING}

This research was supported by the following funding sources: Research Foundation of the State of Minas Gerais - FAPEMIG (Process: 404653/2016-2) and National Council for Scientific and Technological Development - CNPq (Process: APQ-00337-15).

\section{REFERENCES}

1. Ministério da Saúde (BR). Gabinete do Ministro. Portaria n 1.412, de 10 de julho de 2013. Institui o Sistema de Informação para a Atenção Básica (SISAB) [Internet]. 2013 [cited 2018 Apr 10]. Available from: http://bvsms.saude.gov.br/bvs/saudelegis/gm/2013/ prt1412_10_07_2013.html

2. Paz LF, Maran V, Machado A, Augustin A. MECA: Mobile System Support for Brazilian Community Health Agents Program Based on ContextAwareness. IEEE Lat Am Trans [Internet]. 2017 [cited 2018 Apr 10];15(8):1547-55. Available from: https://doi.org/10.1109/TLA.2017.7994805

3. Silva TIM. Difusão da inovação e-SUS Atenção Básica (e-SUS AB) em equipes de saúde da família [Dissertação]. São João del-Rei: Universidade Federal de São João del-Rei [Internet]. 2017 [cited 2018 Apr 10]. Available from: https://ufsj.edu.br/pgenf/dissertacoes_ defendidas.php

4. Sayes E. Actor-Network Theory and methodology: just what does it mean to say that nonhumans have agency? Soc Stud Sci [Internet]. 2014 [cited 2018 Apr 10];44(1):134-49. Available from: https://doi.org/10.1177/0306312713511867

5. Camillis PK, Bussular CZ, Antonello CS. A agência a partir da Teoria Ator-Rede: reflexões e contribuições para as pesquisas em administração. Organ Soc [Internet]. 2016 [cited 2018 Apr 10];23(76):73-91. Available from: https://dx.doi.org/10.1590/1984-9230764

6. Latour B. Reagregando o social. Uma introdução à teoria do Ator-Rede. Salvador: EDUFBA; Bauru: EDUSC; 2012. 
7. Booth RG, Andrusyszyn MA, Iwasiw C, Donelle L, Compeau D. Actor-Network Theory as a sociotechnical lens to explore the relationship of nurses and technology in practice: methodological considerations for nursing research. Nurs Inq [Internet]. 2015 [cited 2018 Apr 10];23(2):109-20. Available from: https://dx.doi.org/10.1111/nin.12118

8. Oliveira AECD, Lima IMBD, Nascimento JAD, Coelho, HFC, Santos SRD. Implantação do e-SUS AB no Distrito Sanitário IV de João Pessoa (PB): relato de experiência. Saúde Debate [Internet]. 2016 [cited 2018 Apr 10];40:212-18. Available from: https://doi. org/10.1590/0103-1104201610917

9. Venturini T. Diving in magma: How to explore controversies with actor-network theory. Public Underst Sci [Internet]. 2010 [cited 2018 Apr 10];19(3):258-73. Available from: https://doi.org/10.1177/0963662509102694

10. Pedro R. Sobre redes e controvérsias: ferramentas para compor cartografias psicossociais. In: Ferreira AAL, Freire LL, Moraes M, Arendt RJJ, organizadores. Teoria Ator-Rede e psicologia. Rio de Janeiro: Nau; 2010. p. 78-96.

11. Venturini T, Ricci D, Mauri M, Kimbell L, Meunier A. Designing controversies and their publics. Des Issues [Internet]. 2015 [cited 2018 Apr 10];31(3):74-87. Available from: https://doi.org/10.1162/DESI_a_00340

12. Jacomy M, Venturini T, Heymann S, Bastian M. ForceAtlas2, a Continuous Graph Layout Algorithm for Handy Network Visualization Designed for the Gephi software. PloS one [Internet]. 2014 [cited 2018 Apr 10];9(6):e98679. Available from: https://doi.org/10.1371/journal. pone.0098679

13. Pinto C, Domenico CS. Análise de dados na Teoria Ator-Rede: Contribuições via cartografia de controvérsias aos estudos em administração. Atas CIAIQ2014 [Internet]. 2015 [cited 2018 Apr 10];3:123-9. Available from: http://proceedings.ciaiq.org/index.php/CIAIQ/article/ view/446/442

14. Ministério da Saúde (BR), Secretaria de Atenção à Saúde, Departamento de Atenção Básica. Ofício Circular 044/2016-DAB/SAS/MS. Suspensão por ausência de envio de informações das equipes de atenção básica por meio de sistema de informação vigente na Atenção Básica - e-SUS AB/SISAB. Brasília (DF): SISAB; 2016.

15. Ministério da Saúde (BR), Secretaria de Atenção à Saúde, Departamento de Atenção Básica. Chamada Pública para o Projeto de Informatização das Unidades Básicas de Saúde (UBS) de Todo Território Nacional (Minuta). Brasília (DF): SISAB; 2017.

16. Ministério da Saúde (BR), Gabinete do Ministro. Portaria no 2.073, de 31 de agosto de 2011. Regulamenta o uso de padrões de interoperabilidade e informação em saúde para sistemas de informação em saúde no âmbito do Sistema Único de Saúde, nos níveis Municipal, Distrital, Estadual e Federal, e para os sistemas privados e do setor de saúde suplementar [Internet]. Diário Oficial da União: República Federativa do Brasil; 2011 [cited 2018 Apr 10] Sept 1. Seção 1: [about 22 screens]. Available from: http://bvsms.saude.gov.br/bvs/ saudelegis/gm/2011/prt2073_31_08_2011.html

17. Conselho Nacional de Secretários de Saúde (CONASS). Nota técnica 07/2013: Estratégia e-SUS Atenção Básica e Sistema de Informação em Saúde da Atenção Básica - SISAB [Internet]. Brasília (DF): CONASS; 2013 [cited 2018 Apr 10]. Available from: http://www.conass.org.br/ biblioteca/wp-content/uploads/2013/01/NT-07-2013-e-SUS-e-SISAB.pdf

18. Conselho Nacional de Secretários de Saúde (CONASS). Nota técnica 08/2014: Situação atual da estratégia e- SUS Atenção Básica [Internet]. Brasília (DF): CONASS; 2014 [cited 2018 Apr 10]. Available from: http://www.conass.org.br/biblioteca/wp-content/uploads/2014/01/NT-082014-e-SUS-e-SISAB.pdf

19. Conselho Nacional de Secretarias Municipais de Saúde (CONASEMS). Nota Técnica 03/2014: Núcleo de Informação em Saúde do CONASEMS Sobre o e-SUS AB [Internet]. Brasília (DF): CONASEMS; 2014 [cited 2018 Apr 10]. Available from: http://www.cosemsrn.org.br/wp-content/ uploads/2016/06/Conasems-N\%C3\%9ACLEO-DE-INFORMA\%C3\%87\%C3\%83O-EM-SA\%C3\%9ADE-E-SUS-AB2.pdf

20. Ministério da Saúde (BR), Secretaria de Atenção à Saúde, Departamento de Atenção Básica. Nota técnica DAB/SAS/MS [Internet]. Brasília (DF): Ministério da Saúde; 2014 [cited 2018 Apr 10]. Available from: http://www.conasems.org.br/wp-content/uploads/2014/07/images_NT_ESUS_SISAB_1.pdf

21. Venturini T, Munk A, Jacomy M. Actor-network VS network analysis VS digital networks are we talking about the same networks? DigitalSTS: A Handbook and Fieldguide, Inpress [Internet]. 2018 [cited 2018 Apr 10]. Available from: https://hal.archives-ouvertes.fr/hal-01672289

22. Guimarães EADA, Hartz ZMDA, Loyola Filho AID, Meira AJD, Luz ZMPD. Avaliação da implantação do Sistema de Informação sobre Nascidos Vivos em municípios de Minas Gerais, Brasil. Cad Saúde Pública [Internet]. 2013 [cited 2018 Apr 10];29(10):2105-18. Available from: http:// dx.doi.org/10.1590/0102-311X00116312

23. Gava M, Ferreira LS, Palhares D, Mota ELA. Incorporação da tecnologia da informação na Atenção Básica do SUS no Nordeste do Brasil: expectativas e experiências. Ciên Saúde Coletiva [Internet]. 2016 [cited 2018 Apr 10];21(3):891-902. Available from: http://dx.doi. org/10.1590/1413-81232015213.01062015

24. Associação Brasileira de Pós-Graduação em Saúde Coletiva (ABRASCO), Grupo Técnico de Informação em Saúde e População (GTISP), organizador. Plano Diretor para o desenvolvimento da Informação e Tecnologia de Informação em Saúde - PlaDITIS 2013-2017: no contexto da atual governança de informação e de implantação do Registro Eletrônico em Saúde/RES. Brasília (DF): ABRASCO [Internet]. 2013 [cited 2018 Apr 10]. Available from: http://www.abrasco.org.br/site/wp-content/uploads/2015/06/GT_informacao_plano-diretor.pdf

25. Pinheiro ALS, Andrade KTS, Silva DO, Zacharias FCM, Gomide MFS, Pinto IC. Gestão da saúde: o uso dos sistemas de informação e o compartilhamento de conhecimento para a tomada de decisão. Texto Contexto Enferm [Internet]. 2016 [cited 2018 Apr 10];25(3):e3440015. Available from: http://dx.doi.org/10.1590/0104-07072016003440015

26. Ministério da Saúde (BR), Secretaria de Atenção à Saúde, Departamento de Atenção Básica. Diretrizes nacionais de implantação da 
estratégia e-SUS Atenção Básica [Internet]. Brasília (DF): Ministério da Saúde; 2014. [cited 2018 Apr 10]. Available from: http://bvsms.saude. gov.br/bvs/publicacoes/diretrizes_nacionais_implantacao_estrategia_esus.pdf

27. Contreiras H, Matta GC. Privatização da gestão do sistema municipal de saúde por meio de Organizações Sociais na cidade de São Paulo, Brasil: caracterização e análise da regulação. Cad Saúde Pública [Internet]. 2015 [cited 2018 Apr 10];31(2):285-97. Available from: http:// dx.doi.org/10.1590/0102-311X00015914

28. Andreazzi MFS, Bravo MIS. Privatização da gestão e organizações sociais na atenção à saúde. Trab Educ Saúde [Internet]. 2014 [cited 2018 Apr 10];12(3):499-18. Available from: http://dx.doi.org/10.1590/1981-7746-sip00019

29. Cardoso FM, Campos GWS. Reformas neoliberais, Reforma Sanitária Brasileira e Fundações Estatais de Direito Privado: análise de documento da Fundação Estatal de Saúde da Família (FESF) - Bahia. Saúde em Debate [Internet]. 2013 [cited 2018 Apr 10];37(97):219-32. Available from: https://www.scielosp.org/pdf/sdeb/2013.v37n97/219-232/pt

30. Campo CMS, Viana N, Soares CB. Mudanças no capitalismo contemporâneo e seu impacto sobre as políticas estatais: o SUS em debate. Saúde Soc [Internet]. 2015 [cited 2018 Apr 10];24(1):82-91. Available from: https://doi.org/10.1590/S0104-12902015S01007

31. Cavalcante RB, Silva JJ, Azevedo JA, Salomé HS, Diniz FA. Percepções sobre instrumentos de coleta de um sistema de informação. J Health Inform [Internet]. 2015 [cited 2018 Apr 10];7(1):16-22. Available from: http://www.jhi-sbis.saude.ws/ojs-jhi/index.php/jhi-sbis/article/ view/330/225

32. Carreno I, Moreschi C, Marina B, Hendges DJB, Rempel C, Oliveira MMC. Análise da utilização das informações do Sistema de informação de Atenção Básica (SIAB): uma revisão integrativa. Ciênc Saúde Coletiva [Internet]. 2015 [cited 2018 Apr 10];20(3):947-56. Available from: http:// dx.doi.org/10.1590/1413-81232015203.17002013

33. Santos TO, Pereira LP, Silveira DT. Implantação de sistemas informatizados na saúde: uma revisão sistemática. Reciis - Rev Eletron Comun Inf Inov Saúde [Internet]. 2017 [cited 2018 Apr 10];11(3):1-11. Available from: https://www.reciis.icict.fiocruz.br/index.php/reciis/article/ view/1064 